\title{
Por Deus, pela Pátria e pelo Rei - Os Holandeses no Rio Grande e a fabricação dos conceitos acerca do espaço na década de $1930^{1}$
}

\section{For God, the Country and the King - Os Holandeses no Rio Grande and the fabrication of the concepts of the space in the 1930s}

\author{
Renato Amado Peixoto*
}

\begin{abstract}
Resumo
Neste texto, retomamos o artigo "Duas Palavras" - publicado em 2014 por esta Revista de História Regional -, para voltar a tratar da invenção da identidade católica norte-rio-grandense, iniciada com a publicação do livro Os Holandeses no Rio Grande em 1937, origem do processo de beatificação dos Protomártires do Brasil. Buscamos, agora, esclarecer certos problemas, como aqueles relativos à Crise de 1935 no Rio Grande do Norte, à colusão do integralismo com o catolicismo, e à compreensão contemporânea da relação entre as escalas do local e do internacional, visando avançar mais na direção de apontar como a ideia da produção de espacializações pode auxiliar na investigação da História Local e Regional.

Palavras-chave: Catolicismo; Colusão; Luís da Câmara Cascudo; Gustavo Barroso; Padre J. Cabral.
\end{abstract}

\begin{abstract}
In this paper, we return to the article "Two Words" - published in 2014 by this Revista de História Regional - to deal, again, with the invention of the Catholic identity in the state of Rio Grande do Norte, which began in 1937 with the publication of the book Os Holandeses no Rio Grande, the source for the beatification of the Protomartyrs of Brazil. Now, we seek to clarify certain issues such as those related to the crisis of 1935 in the Rio Grande do Norte, the collusion between Integralism and Catholicism, and the contemporary understanding of the relation between local and international
\end{abstract}

\footnotetext{
${ }^{*}$ Doutor em História pela UFRJ e professor do Programa de Pós-Graduação e do Departamento de História da UFRN. E-mail: renatoamadopeixoto@gmail.com

${ }^{1}$ Agradeço a colaboração de Douglas André Gonçalves Cavalheiro, meu orientando PIBIC, vinculado ao projeto "O pensamento católico, a atuação política e a intervenção social da Igreja em relação à formulação da identidade e da espacialidade norte-rio-grandense entre 1930 e 1964", desenvolvido na Universidade Federal do Rio Grande do Norte (UFRN). Nosso projeto, está vinculado ao projeto "A Invenção da Terra Potiguar: instituições, intelectuais e agentes políticos na produção da espacialidade e da identidade norte-rio-grandense (1889-1960)" por meio do qual recebeu apoio financeiro do CNPq e da FAPERN.
} 
scale, aiming to advance the idea that the production of spatializations can help the investigation of Local and Regional History.

Keywords: Catholicism; Collusion; Luís da Câmara Cascudo; Gustavo Barroso; Padre Cabral.

Os holandeses haviam fugido, deixando a terra que tanto martirizaram e que se tornou sagrada pelo sangue generoso dos sacrificados por Deus, pela Pátria e pelo Rei.

(Paulo Herôncio, “Os Holandeses no Rio Grande”, 1937, p. 106).

A epígrafe acima, extraída da $1^{\underline{a}}$ edição da obra Os Holandeses no Rio Grande do padre Paulo Herôncio, nos serve como mote para aprofundar certas questões já trabalhadas no artigo 'Duas Palavras', que foi publicado nesta Revista de História Regional no ano de 2014. Entendo que o retorno à 'Duas Palavras' é fundamental não apenas para, a partir de novos resultados de pesquisa, aprofundarmos a compreensão da produção da identidade católica norte-rio-grandense na década de 1930, mas também para se avançar, através das ideias já discutidas, na direção de entender como a produção da espacialidade local articulou a região e a nação revendo um conceito de espaço, o do internacional.

Neste sentido, deve-se lembrar que obra de Paulo Herôncio originou o esforço rumo à beatificação e canonização dos mártires de Cunhaú e Uruaçu, reorganizando a compreensão do conhecido episódio da ocupação holandesa, dos idos coloniais, enquanto reação contra o regionalismo centrado em Recife, o protestantismo, a maçonaria, o liberalismo e as posições da esquerda em sua época.

Neste artigo, em primeiro lugar, buscaremos avançar em relação à 'Duas Palavras', na direção de mostrar que, baseada na compreensão dos eventos de Cunhaú e Uruaçu, a invenção da identidade católica permitiu superar uma verdadeira crise política, institucional, social e moral no Rio Grande do Norte que dividiu também o clero estadual em 1935.

Em segundo lugar, buscaremos assinalar que o esforço de organização dos Congressos Eucarísticos de São José do Mipibu e de Currais Novos em 1936 e 1937, onde se consolidou a compreensão dos eventos de Cunhaú e Uruaçu, dialogou com a ideia acerca da justaposição entre a Nação e a Igreja Católica, defendida pela Ação Católica Brasileira e pelo Centro Dom Vital por 
meio de seu líder, Tristão de Athayde, explicitando a posição do clero e do laicato norte-rio-grandense.

Em terceiro lugar, apontaremos que a escrita de Os Holandeses no Rio Grande se deu em meio à radicalização política de seu tempo e teve que debater com as posições colusivas ${ }^{2}$ de boa parte do clero e do laicato norte-rio-grandense, reunidos na "Congregação Mariana" de $\mathrm{Natal}^{3}$ e, com as ideias e liderança do padre José Cabral. É de autoria deste padre, a obra mais expressiva do período - A Questão Judaica - que influenciou não apenas a escrita de Paulo Herôncio, mas antecedendo a tradução anotada dos "Protocolos dos Sábios do Sião" de Gustavo Barroso, também influenciou a este e a Luís da Câmara Cascudo.

Finalmente, cabe recordar que a $2^{\mathrm{a}}$ edição de Os Holandeses no Rio Grande omitiu o prefácio da $1^{\mathrm{a}}$ edição, de autoria do padre José Cabral, a maior parte do penúltimo capítulo, "Os terços de Henrique Dias" e todo o último capítulo, "Redenção" - do último parágrafo deste capítulo se recorta a epígrafe deste artigo. E, mais do que uma omissão, podemos apontar que a falta dessa parte do texto na $2^{\mathrm{a}}$ edição constitui uma excisão e, como tal, apresenta o problema que guiará este artigo. ${ }^{4}$

\footnotetext{
${ }^{2}$ O termo "colusão" e suas adjetivação colusivo(a) foi criado por Roger Griffin, que apontou que o concerto dos pesquisadores em torno da aproximação entre o fascismo e o cristianismo dever-se-ia guiar pela ideia da confluência e síntese de posições antitéticas, com a transformação das crenças religiosas para que estas se adaptassem ao fascismo. Trata-se, assim, não apenas de apontar que membros laicos e religiosos da instituição religiosa houvessem aderido ou formado taticamente em um dado movimento fascista, mas que houvesse a tentativa de harmonizar, conformar ou transformar a religião na direção do movimento ou de uma facção do fascismo e desta, em direção ao religioso. Por conseguinte, não se busca examinar uma síntese ou fusão das posições do político e do religioso, mas pensar o seu entrelaçamento, especificidade que torna esse envolvimento - o Fascismo Clerical - um fenômeno político relativamente raro, embora se reconheça o largo envolvimento das denominações cristãs com o fascismo no Entreguerras. PEIXOTO, Renato Amado. Creio no espírito cristão e nacionalista do Sigma: Integralismo e Catolicismo nos escritos de Gustavo Barroso, Padre J. Cabral e Câmara Cascudo, In: RODRIGUES, Cândido M; ZANOTTO, Gizele; CALDEIRA, Rodrigo Coppe. (Orgs.). Manifestações do pensamento católico na América do Sul. 1ed. São Paulo: Fonte Editorial, 2015, p. 111.

${ }^{3}$ PEIXOTO, Renato Amado. A Colusão entre o Catolicismo e o Integralismo no Rio Grande do Norte (19321935). In: XXVIII SIMPÓSIO NACIONAL DE HISTÓRIA, 2015, Florianópolis. Anais eletrônicos do XXVIII Simpósio Nacional de História. São Paulo: Anpuh Nacional, 2015.

${ }^{4}$ Por excisão, aponto tanto o termo quanto o conceito trabalhado por Jacques Derrida em "Circonfissão" e nas discussões de "Augustine and postmodernism". No texto homônimo, o termo "circonfissão" encerra um jogo de palavras entre confissão e circuncisão, por meio do qual Derrida deixava claro ter extrapolado a história da confissão em direção à história da circuncisão, visando juntar o sentido do termo "excisão" ao de "confissão". De modo a bem esclarecer esse jogo de palavras e o significado dele na discussão do problema da Memória, devo lembrar que Excisão não significa o mesmo que Extração, pois, excisar tem sempre o sentido de amputar, extirpar, mutilar, amputar, ou seja, remover deixando marcas ou faltas, exatamente o caso da circuncisão, sentido que guiará este artigo. Contudo, não seria em "Circonfissão" que a excisão seria indicada por Derrida como um problema para os historiadores, mas sim em "Au-
} 
Nesse sentido, há que se considerar que Paulo Herôncio articulou o local com o regional e o nacional por meio de uma reflexão sobre outro conceito de espaço em que o universalismo cristão era justaposto colusivamente ao internacionalismo soviético, numa espacialização ${ }^{5}$ que considerava as preocupações mais gerais da Igreja brasileira e do catolicismo mundial, a partir das considerações de padre José Cabral. Portanto, a partir de suas próprias impressões sobre o Levante Comunista de 1935 no Rio Grande do Norte e sobre a Guerra Civil Espanhola, e nos mostrando que o historiador do local e do regional precisa também pensar o fazer da História como experimentação. ${ }^{6}$

\section{A Crise de 1935 no Rio Grande do Norte}

Paulo Herôncio de Melo exerceu até 1933 as funções de vigário e prefeito de Macau - cidade do interior do Rio Grande do Norte -, e essa atuação política, mais próxima dos políticos destituídos do poder pela Revolução de

\footnotetext{
gustine and Postmodernism" - livro editado por John D. Caputo, onde insistiu que os historiadores não deveriam se desinteressar do status daquilo que estavam analisando e interpretando. Isso foi colocado em meio ao debate que fazia então com seus entrevistadores, ao ser lembrado por esses de que muitos historiadores rejeitavam a história intelectual argumentando trabalhar com documentos e não em textos e, que eles o faziam provavelmente para poder deixar de lado as questões levantadas pela teoria literária e filosófica. Utilizando o exemplo fornecido por "Circonfissão", Derrida apontou que o exame das histórias da confissão e das histórias da circuncisão foi o que lhe permitiu explorar a ideia da excisão nos textos que começara a trabalhar ao início da investigação, muitos anos antes da escrita de "Circonfissão". Assim, Derrida relacionaria a questão da Excisão à Memória, buscando o debate com a obra Confissões de Santo Agostinho e o diálogo com as aproximações feitas por Heidegger, Ricœur, Lyotard e Hanna Arendt. Grosso modo, Derrida apontaria que "confessar" significa dizer "eu me lembro", um ato em que os sentidos da memória e da lembrança se embaraçam nas ideias de permanência e pertinência, remetendo o historiador a ter de inquirir, também, os sentidos da verdade e da temporalidade à confissão. PEIXOTO, Renato Amado. O Fantasma de Gustavo Barroso e o Espectro da Nação. In: DANTAS, Elynaldo. Gustavo Barroso, o Führer brasileiro: Nação e identidade no discurso integralista barrosiano de 1933-1937. Natal: Ideia, 2015, p. 12-14.

${ }^{5}$ A espacialização seria uma operação em que vários espaços e tempos foram tomados conjuntamente - outras espacializações, locais, regionais e nacionais. 0 sentido da espacialização não é apenas passivo ou dirigido, mas ativo e também reflexivo. Toda espacialização é uma des-espacialização e uma des-constituição de outras espacializações precedentes ou contemporâneas e que, enquanto desloca - ativa e masculinamente-, a espacialização também recebe e concebe - passiva e femininamente -, possibilitando-se, deste modo, o deslizamento do tempo para a alocação do inventado, fabricado ou reelaborado - o Mito. Assim, a espacialização é a operação em que vários espaços e tempos locais, regionais e nacionais são conjuntamente tomados/recebidos. Nessa operação, o espaçamento do tempo - como no sonho -, permite-nos dizer da investigação do espaço e do tempo na cumplicidade, de sua origem comum e desse comparecer como condição de todo aparecer do ser, esse sentido de com-parecimento que pretendo situar um sentido de investigação da História Local e Regional - o das operações que produzem as identidades e as espacialidades. PEIXOTO, Renato Amado. Duas Palavras: Os Holandeses no Rio Grande e a invenção da identidade católica norte-rio-grandense na década de 1930. Revista de História Regional, v. 19, p. 35-57, 2014, p. 56-57, nota 45.
}

${ }^{6}$ PEIXOTO, O fantasma... op. cit., p. 22. 
1930, separaria padre Herôncio das posições defendidas pela Diocese de Natal e por seu bispo, D. Marcolino Dantas, até o Levante Comunista de 1935.

De fato, D. Marcolino vinha desde 1930 desenvolvendo uma vigorosa política de apoio aos interventores federais, visando com isso expandir a atuação política da Igreja e sua presença na administração, inclusive, buscando viabilizar, sob seu comando, a já planejada expansão da estrutura diocesana para outras duas cidades, Caicó e Mossoró que, respectivamente, eram os centros das atividades algodoeira e salineira no estado. Mobilizando a intelectualidade e as elites mais afinadas com sua liderança, guiada pelas ideias do reacionarismo católico, D. Marcolino inspirou a fundação do jornal A Ordem, porta voz das posições da Diocese, e a criação de agremiações políticas como a Ação Integralista e a Aliança Social, reunindo as forças políticas que enfrentaram nas urnas os inimigos dos Interventores.

O fato é que antes do Levante Comunista, sinalizando a divisão na Igreja Católica norte-rio-grandense, padre Herôncio e D. Marcolino já militavam, politicamente, em campos opostos. O primeiro, vigário de São José do Mipibu, apoiando o Partido Popular e as forças decaídas; o outro, Bispo de Natal, sustentando a Aliança Social e o interventor Mário Câmara, membro de tradicional família natalense, indicado diretamente por Getúlio Vargas para esse posto.

Essa profunda cisão no clero e nas elites norte-rio-grandenses havia se tornado ainda mais profunda pelo enfrentamento aberto de duas novas forças, o comunismo e o integralismo, movimentos que adquiriram ampla difusão no estado, sobretudo pela vitalidade de suas forças dinamizadoras. No primeiro caso, os sindicatos, alargados pela antiga liderança de João Café Filho, membro da Aliança Social; no segundo, pela atuação da Congregação Marista, apoiada pelo Bispo Diocesano.

Em 1935, esta cisão ganhou o contorno de uma extensa crise - social, moral, religiosa e política -, demonstrada pelo grande número de greves, atentados, assassinatos e espancamentos de membros dos grupos políticos, empastelamento de jornais, insubordinação de grupos armados contra o governo estadual, e pela guerrilha rural, acionada e apoiada pelo Partido Comunista e pelo Sindicato dos Operários das Salinas de Mossoró. ${ }^{7}$

\footnotetext{
${ }^{7}$ PEIXOTO, Renato Amado. A Crise de 1935 no Rio Grande do Norte: a tensão entre as identidades estadual e nacional por meio do caso norte-rio-grandense. In: VI Simpósio Internacional Estados Americanos Pesquisas acadêmicas contemporâneas, 2012, Natal. Anais do VI Simpósio Internacional Estados Contemporâneos. Natal: UFRN, 2012. v. 1. p. 294-301.
} 
Contudo, a crise de 1935 no Rio Grande do Norte ganhou um delineamento ainda mais agudo pela ampla exposição das posições radicais nas páginas dos jornais norte-rio-grandenses, especialmente em 0 Debate, ligado à Interventoria; A Razão, editado por Elói de Sousa para apoiar as posições do Partido Popular; e A Ordem, da Congregação Mariana, para sustentar a atuação da Diocese e da Ação Integralista. Esse radicalismo frequentemente foi sublimado por ataques pessoais à liderança de Elói de Sousa - ex-senador pelo estado - e de D. Marcolino.

Esses ataques ganharam, inclusive, repercussão nacional, ao serem publicados como matéria paga no Rio de Janeiro e, especialmente um deles que, assinado pelo ex-governador Juvenal Lamartine, acusava o Bispo de Natal de cumplicidade e acobertamento dos crimes políticos cometidos por Mário Câmara.

Da parte dos católicos ligados à liderança de D. Marcolino, essa radicalização transbordara para a identificação das elites decaídas com a maçonaria e também no ataque ao protestantismo, ao espiritismo, às religiões afro-brasileiras e ao comunismo. Essa atitude resultou ainda na aproximação de alguns de seus líderes e intelectuais norte-rio-grandenses, caso de Ulisses de Góis, Luís da Câmara Cascudo e Otto de Brito Guerra, com o integralismo e suas facções mais extremadas, como se pode constatar em seus escritos e, pelas páginas do jornal A Ordem.

Em meio a tudo isso, a maior força do Exército no estado, o $21^{\circ}$ Batalhão de Caçadores, já transferido de Recife para Natal em razão de ter se rebelado contra o governo local, fazia parte do jogo político, com seus oficiais sendo assediados pelo Partido Popular e pela Aliança Social e, seus praças e sargentos, pela propaganda do Partido Comunista. Essa tensão se acumulou desde as eleições de 1934 e não se resolveu em 1935, mesmo com a declaração da vitória do Partido Popular após a recontagem dos votos no pleito suplementar, e com a subsequente eleição indireta e posse de Rafael Fernandes como governador do Rio Grande do Norte.

Portanto, entendo que os acontecimentos de novembro de 1935 - a tomada da capital e de parte do interior do estado pelos revolucionários comunistas guiados pelos militares do $21^{\circ} \mathrm{BC}$, somada à guerrilha rural -, foram os responsáveis por aplainar as diferenças mais agudas entre as elites e de unificar o clero em torno da liderança diocesana. O Levante Comunista impactou, sobremodo, os católicos norte-rio-grandenses e as elites decaídas e, ao final, nas palavras do diretor do conselho da Congregação Mariana e Vigário-Geral da Diocese de Natal - monsenhor José Alves Landim -, 
tornava-se preciso "prevenir levantes futuros, criando uma mentalidade anticomunista". 8

Para este objetivo, o concurso de padre Herôncio mostrou-se decisivo, pois, como vigário de São José do Mipibu, ficaria responsável por organizar naquela cidade o primeiro Congresso Eucarístico diocesano em 1936, cujo lema também cunhou: "Louvado seja o Santíssimo Sacramento", lembrando as últimas palavras proferidas por Matias Moreira, martirizado em Uruaçu durante a Invasão Holandesa ao Rio Grande do Norte, recolhidas, segundo a organização do Congresso, da 'História do Brasil' escrita por Rafael Maria Galanti. ${ }^{9}$

\section{Os Congressos Eucarísticos de São José do Mipibu e de Currais Novos}

o Congresso Eucarístico de São José do Mipibu adiantava, portanto, o tema do livro de Paulo Herôncio, Os Holandeses no Rio Grande, e essa primeira conexão deve ser sublinhada, pois se buscava, após o Levante Comunista, unir o clero diocesano e as elites estaduais e, simultaneamente, através da história local, se procurava produzir uma identidade norte-rio-grandense por meio do catolicismo, da referência ao martírio pela fé e da resistência ao invasor estrangeiro.

Por sua vez, D. Marcolino, em Cunhaú e Uruaçu, realçava que também se perpetrava a memória dos que haviam dado seu sangue pela religião e pela pátria, entendendo, por conseguinte, que os seus mártires eram marcos de fé e de patriotismo não apenas do Rio Grande do Norte, mas de todo o Brasil, nascido desses episódios. ${ }^{10}$

Tanto Paulo Herôncio como D. Marcolino seguiram a linha apontada por Tristão de Athayde que - juntando o contexto da crise estadual àquilo que era entrevisto como uma crise nacional e universal -, apontava o papel da Igreja Católica na fundação e sedimentação de uma civilização brasileira.

Athayde ainda discernia a disputa ideológica do catolicismo com o comunismo, para defender que o universal se sobrepunha ao internacional para buscar o fim das fronteiras e barreiras tarifárias rumo ao congraçamento entre os povos, e que o aporte do universalismo permitiria ao Brasil ultrapassar as barreiras colocadas por um regime de ideias em que o Estado se opunha à Religião, impondo o imperialismo e a beligerância.

\footnotetext{
${ }^{8}$ CÚRIA METROPOLITANA. Livro de Tombo da Catedral, n. 3, Diocese de Natal, 1935.

9 "Exemplificação do Lema do Congresso". A Ordem, Natal, 25 out. 1936, p. 4.

${ }^{10}$ DANTAS, Marcolino. Homilia no Seminário São Pedro, 3 out. 1947. In: MEDEIROS, José Mario de. Dom Marcolino Dantas: por ele mesmo. Brasília, DF: Senado Federal, 2009, p. 118-119.
} 
O Brasil separado da Igreja, ou seria uma colônia miserável e esquecida do Império Soviético Universal, se a figura do mal for uma, só em toda a terra como querem os seus utopistas, -ou será um bloco jacobino, fechado em suas fronteiras e em sua língua, sobranceiro a outros blocos idênticos, mais cioso dos seus direitos que dos seus deveres, cercado de barreiras de aço ou de tarifas, e pronto para entrar ingloriosamente em lutas de recíproco extermínio.

O Brasil ligado à Igreja, porém, por toda a sua história, por toda a sua alma, por todo o significado profundo de sua civilização, será uma grande pátria, nacional e universal, fiel aos países mais típicos dessa sua civilização ao mesmo tempo doméstica, jurídica, cultural e religiosa. ${ }^{11}$

Cabe, neste ponto de reflexão do artigo, notar que a fabricação da identidade estadual por meio do recurso ao nacional seria adensada logo em 1937 pelas solenidades de rememoração do Congresso Eucarístico de São José do Mipibu, lideradas por Paulo Herôncio e por Luís da Câmara Cascudo, e pela organização, na cidade de Currais Novos, do Segundo Congresso Eucarístico do Estado, sediado na região do Seridó norte-rio-grandense , baluarte da resistência contra o Levante Comunista de 1935 e, próximo do sítio da 'Batalha da Serra do Doutor', palco do maior enfrentamento entre as forças revolucionárias e seus antagonistas no Rio Grande do Norte.

É interessante observar que na solenidade de rememoração do Congresso Eucarístico de São José do Mipibu, antes da palestra de Luís da Câmara Cascudo sobre Dom Bosco, ponto culminante da programação, ele lembrou que, em sinal de fé, todos os presentes deveriam rezar o Credo, como se havia feito naqueles dias de 1936.

Esse pedido, vindo de alguém que era não apenas um líder leigo do catolicismo, mas também uma das figuras mais destacadas do Integralismo radical no Brasil e no Rio Grande do Norte, não deve deixar de ser relacionado com as apropriações do Credo que então estavam sendo feitas por Gustavo Barroso e por Plínio Salgado, e que implicavam em distintos posicionamentos frente à disputa que então se fazia pela preeminência no movimento integralista, nos levando a ter de raciocinar como e, em que circunstâncias, a religião e a política estavam imbricadas em $1937 .{ }^{12}$

No caso do Congresso Eucarístico de Currais Novos, organizado também por Paulo Herôncio, deve-se apontar que, em espelho das representações

\footnotetext{
11 “A. B. C.”. A Ordem, Natal, 14 out. 1937, p. 1.

${ }^{12}$ Coloco em questão não apenas a "colusão" entre o catolicismo e o fascismo, mas também a separação entre a religião e o laicismo na modernidade, observadas nas diferentes apropriações do Creio pelos integralistas em meados da década de 1930 - cf. PEIXOTO, Creio no espírito cristão... op. cit., p. 99-101.
} 
disponibilizadas pela Arquidiocese do Rio de Janeiro, o centro de poder da Igreja Católica brasileira, as festividades do Congresso Eucarístico de Currais Novos em 1937, seriam realizadas ao pé da estátua do "Cristo do Seridó", mandada construir especialmente para o evento por Manoel Salustino, uma das principais forças políticas da cidade.

Observe-se, na direção de nosso argumento - além da óbvia semelhança entre essa estátua com a do Corcovado (Figura 1) -, que a nomeação de "Cristo Redentor" foi utilizada por Thomaz Salustino, juiz de Direito de Currais Novos e filho de Manoel Salustino, em informe feito a Paulo Herôncio sobre os preparativos do Congresso Eucarístico. ${ }^{13}$

Figura 1 - Monumento e Estátua do Cristo do Seridó

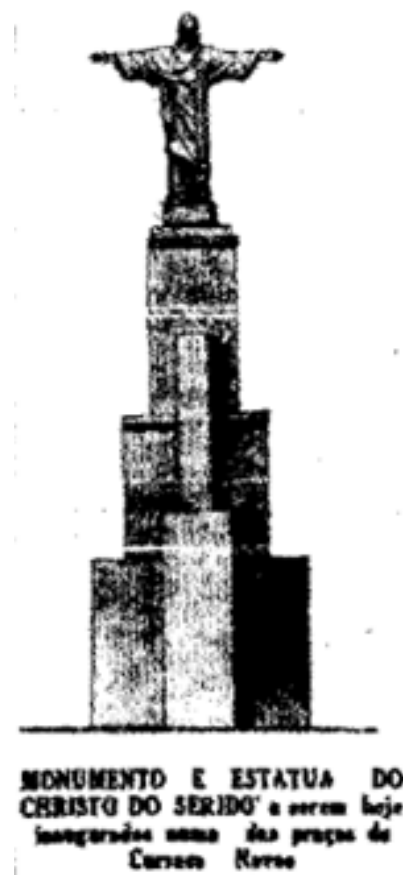

Fonte: Jornal A Ordem, 28 out. 1937

\section{A Colusão do Catolicismo com o Integralismo}

O registro da ligação entre religião e pátria seria encadeado novamente por Luís da Câmara Cascudo na sua contribuição à fabricação da "mentali-

13 “Congresso Eucharistico Parochial de Curraes Novos”. A Ordem, Natal, 5 ago. 1937, p. 4. 
dade anticomunista" norte-rio-grandense, quando este se posicionou simultaneamente como líder integralista e católico frente à grande manifestação destinada a comemorar e reintroduzir os crucifixos nas salas de aula, patrocinada pela Diocese de Natal e pelo Governo do Estado em 1937:

Foi com o sangue do Jesuíta que se batizou a terra de Vera Cruz, em continuação ao batismo que a própria Cruz realizara quando foi fincada em terra firme, no dia de sua invenção, em 1500. Quem, como nós possui tradições tão firmes e tão nobres tem o dever de defendê-las e projetá-las no futuro [...]. Satanás deixou o seu covil subterrâneo e alojou-se em Moscou, de onde dirige uma guerra sem tréguas contra Jesus Cristo e sua Igreja. $O$ comunismo é o exército de Satanás que tenta destruir a religião, a família, a pátria, os direitos naturais do homem e os direitos divinos. ${ }^{14}$

Notando-se que a contribuição de Luís da Câmara Cascudo alinha-se com sua interpretação dos episódios de Cunhaú e Uruaçu, conforme apontado em "Duas Palavras", julgo que outras conexões do livro de Paulo Herôncio devem ser observadas: a recepção e o diálogo das obras coevas.

Os primeiros registros dos episódios de Cunhaú e Uruaçu datam de 1648, incluídos por Manuel Calado no "Valeroso Lucideno", mas sua disseminação nos escritos da década de 1930 se deve à sua republicação, em separata, pelo Arquivo Nacional, nos anos de 1922 e 1929 com o título de "Breve, verdadeira e autêntica Relação das últimas tiranias e crueldades que os pérfidos dos holandeses usaram com os moradores do Rio-Grande".

Às duas edições desta separata se deve somar o efeito da republicação, em 1930, no livro Aventura e Aventureiros no Brasil do texto "Um intérprete dos Tapuias", a biografia de Jacob Rabbi escrita em 1909 por Alfredo de Carvalho e também publicada, quatro anos depois de "Os Brasões de Armas do Brasil Holandês", na Revista do Instituto Arqueológico e Geográfico Pernambucano. ${ }^{15}$

Seria a partir da recepção dessas republicações, mas condicionada pela onda de antissemitismo católico estimulado no Brasil pela publicação em 1931 da obra Forças Secretas da Revolução de Léon de Poncins, que Luís da Câmara Cascudo começaria a apontar já em 1931 o interesse nos acontecidos em Cunhaú e Uruaçu, para finalmente, em 1936, na plaquete "O Brasão Holandês do Rio Grande do Norte", articular sua interpretação com as posições expostas por Gustavo Barroso na "História Secreta do Brasil", que

\footnotetext{
${ }^{14}$ A extraordinária concentração cívico-religiosa de ontem, na praça André de Albuquerque. A Ordem, Natal, 29 out. 1937, p. 1.

${ }^{15}$ PEIXOTO, 2014, op. cit., p. 35-57.
} 
vinha sendo publicada em capítulos, nesse ano, pelo jornal A Offensiva. ${ }^{16}$ Escritos em colaboração, estes dois textos frisavam as posições de Cascudo e Barroso nas disputas internas ao Integralismo, em torno do anti-imperialismo, anticapitalismo e antissemitismo, centrando a interpretação da trama do episódio de Cunhaú e Uruaçu na atuação do judeu Jacob Rabbi.

Deve-se considerar que esses textos refletiam também as posições colusivas e antijudaicas expressas ainda em 1936 por outro norte-rio-grandense, o padre José Cabral em "A Questão Judaica" e, note-se que o padre José Cabral era próximo tanto intelectual quanto pessoalmente dos dois integralistas, e também de Paulo Herôncio. ${ }^{17}$

Neste ponto, cabe registrar que minha pesquisa permitiu constatar que "A Questão Judaica" é anterior à publicação da versão brasileira dos "Protocolos dos Sábios do Sião", provavelmente influenciando não apenas Barroso, mas uma boa parte da literatura antissemita da sua época. Seguindo esse raciocínio, acreditamos que as posições de padre José Cabral foram endossadas por Gustavo Barroso no prefácio de "A Questão Judaica" e que as posições expressas no prefácio foram realinhadas, pouco depois, na sua ampliação e anotação dos "Protocolos dos Sábios do Sião". ${ }^{18}$

No diálogo com essas obras, Paulo Herôncio primeiro firma posição em Os Holandeses no Rio Grande contra a interpretação dos episódios de Uruaçu e Cunhaú feita por Gustavo Barroso na História Secreta do Brasil. Neste texto, Barroso apontara que muitos em Uruaçu haviam se suicidado para

\footnotetext{
${ }^{16}$ BARROSO, Gustavo. História Secreta do Brasil. Vol. 1 Do descobrimento à abdicação de D. Pedro I. $1^{\mathrm{a}}$ ed. São Paulo: Companhia Ed. Nacional, 1937. CASCUDO, Luis da Câmara. O Brasão Holandês do Rio Grande do Norte. Revista do Instituto Histórico e Geográfico do Rio Grande do Norte. Natal. v. XXXV-XXXVII, 1941, p. 91.

${ }^{17}$ O padre José Maria Lustosa Cabral, nasceu em Natal no ano de 1897 e foi ordenado nessa cidade, no ano de 1920, tendo exercido suas funções no estado do Rio Grande do Norte até se transferir em 1925 para São Paulo, onde foi diretor do Instituto D. Sebastião Leme. Em 1929 foi a Europa e visitou a França, Suíça, Espanha e Itália, talvez travando nesse momento seu primeiro contato direto com o Fascismo. Desde 1930 tornou-se colaborador de diversos jornais carioca, especialmente o Correio da Manhã e o Jornal do Brasil. Foi diretor do jornal da Diocese do Rio de Janeiro, A Cruz, e representava constantemente o bispo de Natal, D. Marcolino Dantas, junto ao Cardeal D. Sebastião Leme, tendo, inclusive, feito parte do colegiado de S. Pedro, onde lhe foi dado o título de Cônego, com o ofício teologal. Assinando como Padre J. Cabral escreveu e traduziu diversas obras de devoção católicas, como Jesus Cristo Rei dos Reis, sendo que algumas destas ainda têm sido reeditadas recentemente, como a Imitação de Cristo. Suas obras no campo da moral e da teologia tiveram várias edições e boa divulgação, como Limitação da Natalidade, No terreno dos Princípios e Lutas da Mocidade. Também se destacou no campo político tendo algumas de suas obras grande repercussão e várias edições, como A Miragem Soviética (1933), A Questão Judaica (1937) e A Igreja e o Marxismo (1949).

${ }^{18}$ Ao contrário do senso comum historiográfico, o texto do padre J. Cabral já estava no prelo da Livraria do Globo antes de ser publicada a versão brasileira dos Protocolos. Inclusive, a influência de Cabral sobre Barroso pode ser depreendida na leitura do prefácio de A Questão Judaíca, que foi escrito pelo próprio Barroso e, portanto, antes da publicação dos "Protocolos". Ver PEIXOTO, Creio no espírito cristão... p. 113-114.
} 
escapar dos suplícios infringidos pelos invasores. Paulo Herôncio, por sua vez, explica esse fato pela ótica do catolicismo, ou seja, que o suicídio seria uma atitude incompatível com a fé e, além disso, com a condição de patriota daqueles que estavam em Uruaçu, não havendo, nos dois sentidos, quaisquer possibilidades, seja de pusilanimidade, seja de covardia. ${ }^{19}$

Posteriormente, Paulo Herôncio se afastaria também das posições antissemitas e fascistas empregadas por Gustavo Barroso e Luís da Câmara Cascudo para explicar a relação de Jacob Rabbi com os holandeses. Herôncio procura tratar de Rabbi mais como um agente dos invasores, desconstituindo ainda a pecha atribuída aos seus direcionados e generalizada por aqueles dois autores em direção aos indígenas como um todo. Os comandados de Rabbi são vistos em Os Holandeses no Rio Grande, sobretudo, como uma das facções beligerantes, e Herôncio ressalta que Felipe Camarão, um dos indígenas, foi o grande protagonista da luta contra os invasores e, frisa, a favor do catolicismo, descrevendo Camarão como um guerreiro-católico, temente a Deus, portanto, destituído de medo e em paz consigo mesmo. ${ }^{20}$

\section{O diálogo com o padre José Cabral e o internacionalismo de Cristo}

Finalmente, no que cabe ao diálogo com o padre José Cabral, prefaciador de Os Holandeses no Rio Grande, cabe-nos colocá-lo numa relação que problematiza e tensiona os problemas da memória, da verdade e da temporalidade, na medida em que sua fabricação se revela nos termos de uma experimentação.

Repensar conceitos já estabelecidos como os de região ou do internacional e incuti-los na espacialidade e na identidade locais é um processo complexo que revela resgates, acréscimos, escolhas e excisões, mas, sobretudo, deve ser pensado além da grade do arcaísmo, para ser também inquirido aos modos de pensar e de se fazer lembrar o passado. ${ }^{21}$

Nesse sentido, devemos observar que os Congressos Eucarísticos de São José do Mipibu e de Currais Novos não apenas serviam à fabricação de uma identidade local, mas também refletiam os problemas colocados pela Região: sua interação com a produção historiográfica da Nação e com os posicionamentos do catolicismo, interna e externamente ao Brasil.

\footnotetext{
${ }^{19}$ HERÔNCIO, Paulo. 'Gustavo Barroso e os Mártires de Uruassú'. A Ordem, Natal, 05 mar. 1937, p. 1.

${ }^{20}$ PEIXOTO, Duas Palavras..., p. 35-57.

${ }^{21}$ PEIXOTO, O fantasma de Gustavo Barroso..., p. 21.
} 
Em “Duas Palavras” procurei discernir a produção de espacializações como um dos sentidos de investigação da História Local e Regional, apontando que no caso norte-rio-grandense vários espaços e tempos - outras espacializações, locais, regionais e nacionais -, foram tomadas conjuntamente, e que esse sentido explicaria uma operação não apenas passiva ou dirigida, mas ao mesmo tempo também ativa e reflexiva. ${ }^{22}$

Agora, procuro aclarar que, em muitos exames, não basta nos interessarmos pela produção histórica ou historiográfica dessas espacializações, mas que se torna necessário questionar e inquirir os próprios conceitos acerca do espaço (região, nação, internacional, universal) a partir dos quais nos aproximamos do objeto a ser trabalhado. ${ }^{23}$

Como vimos, no caso da fabricação da identidade católica norte-rio-grandense, ela tensiona o universal para contrapô-lo ao internacional a partir do ponto de vista do catolicismo e, penso que, de outro modo, o nacional também foi tensionado, em sua vez, para superpor-se ao regional.

No caso, a reação católica à orientação da produção da região em Recife, que colocava Pernambuco no centro da sua narração histórica, se dá numa relação pontual com o debate acerca da figura de Nassau e sua contribuição para a formação cultural e histórica daquela cidade, questão colada em debate pelo próprio periódico da Diocese de Natal, repercutindo as discussões feitas, no Centro Dom Vidal para serem divulgadas pela revista $A$ Ordem e demais periódicos católicos.

Em Os Holandeses no Rio Grande do Norte, se constitui uma linha interpretativa que frisa o caráter predatório, exploratório e colonialista da presença holandesa no Rio Grande do Norte, deixando entrever o papel desempenhado pelo protestantismo enquanto partícipe da opressão cultural e capitalista do invasor, violências impostas pela força militar e perpetradora do genocídio contra os naturais da terra, exemplificada nos episódios de Cunhaú e Uruaçu.

Esta leitura, muito provavelmente, derivava das observações de parte dos católicos acerca da invasão italiana da Etiópia, problema contemporâneo à escrita de Paulo Herôncio e desencadeadora de outra leitura, cruzada, mais uma vez, com as posições do fascismo brasileiro do período, algumas

\footnotetext{
${ }^{22}$ Ver nota 45, p. 56-57, em: PEIXOTO, Duas Palavras... p. 35-57.

${ }^{23}$ Nessa aproximação trabalho a partir da ideia de Reinhart Koselleck de que duas condições de investigação do espaço se apresentam aos historiadores: a "história dos conceitos do espaço" e a "história dos espaços". PEIXOTO, Renato Amado. Zona de confluxo: a investigação da historicidade do espaço por meio do exame do afastamento da História em relação à Geografia. Revista Porto, v. 1, n.1, 2011, p. 111-126.
} 
delas favoráveis ao feito de Mussolini, mas, também, denunciadoras do imperialismo, tensão esta que cobre boa parte das obras do período integralista de Gustavo Barroso.

Contudo, Os Holandeses no Rio Grande repercute outra violência e outro genocídio, entrevistos por Paulo Herôncio na atuação dos comunistas e dos anarquistas contra o clero e os fiéis católicos durante a Guerra Civil Espanhola. Este conflito não era entendido por Herôncio apenas como uma disputa política, mas como uma guerra contra a religião como um todo e, contra os católicos em particular, adicionando mais um sentido para o anticomunismo.

Não se tratava apenas de rejeitar a modernidade, ou de combater os maçons, protestantes ou se opor ao comunismo. Este é o último sentido tomado a granel por aqueles que interpretam a história política sem notar que, no caso do catolicismo, se faz necessário tomá-lo junto à História da Religião.

O anticomunismo era apenas uma das faces de um contradiscurso católico muito amplo, voltado primeiramente contra o protestantismo e, a partir do século XIX, também contra as diversas forças e posições sintonizadas com o laicismo e o antirreligiosismo, reunidas pelos católicos no rótulo bastante abrangente de combate à modernidade. Nesse sentido, as diversas correntes da direita católica, desde o conservadorismo até o fascismo, lançavam mão de uma linguagem que explicitava - não apenas para uma audiência externa, mas também para os próprios católicos -, suas representações do campo político a partir do religioso, uma rica dicotomia, difícil de perceber por aqueles que não estão afeitos a este debate. ${ }^{24}$

No caso do diálogo entre Paulo Herôncio e o padre José Cabral, este se dá a partir da digressão de Cabral a respeito do conceito de internacionalismo e com os sentidos que se emprestavam à constituição de um conceito mesmo do internacionalismo católico - o "internacionalismo de Cristo. Esse internacionalismo seria irredutivelmente oposto ao internacionalismo soviético e adstringente do conceito de região, pois tratava-se de distinguir que o internacionalismo soviético procurava derrubar as fronteiras, para com elas elidir a todas as diversidades.

Paradoxalmente, para padre José Cabral, ensinar "as grandes lições de heroísmo e amor pátrio e reviver as tradições" era emprestar um novo sentido à ideia do universalismo e do internacionalismo, para forjar, com isso, a ideia de uma comunidade transcendente baseada na civilização cristã.

${ }^{24}$ PEIXOTO, Creio no espírito cristão..., p. 99-101. 
Essa comunidade ideal, a se materializar no tempo presente, atravessaria os sentidos de fronteira, raça e cultura, sublimando-os como fator aglutinador, acolhedor e pacificador dos povos. Isso possibilitaria a Paulo Herôncio, por conseguinte, conduzir a ideia da região ao reconhecimento do esforço pregresso do catolicismo e à resistência ao elemento imperialista, sublimado no esforço dos indígenas em geral e, em Felipe Camarão, no particular. ${ }^{25}$

\section{Verdadeira Barbaria}

Por outro lado, a identidade católica norte-rio-grandense forjada no Congresso de São José do Mipibu e no livro de Paulo Herôncio, juntaria num só raciocínio o Levante Comunista e a invasão holandesa do Rio Grande, a partir da recepção da perseguição e do genocídio católico na Espanha.

Dois rastros desse raciocínio foram deixados em "Os Holandeses no Rio Grande”, um por seu prefaciador, o padre José Cabral e outro pelo próprio autor, na última linha de sua obra. No seu prefácio para Os Holandeses no Rio Grande, o padre José Cabral apontava que "atravessamos uma época tumultuosa, que alguns comparam aos últimos dias do Império Romano; vivemos dias agitados, que nos trazem mais receios que esperanças". ${ }^{26}$

Foi esse o sentido da luta pela sobrevivência da religião - uma guerra sem quartel e sem limites, que não poupava vivos e mortos -, que se decidia tanto nos campos de batalha quanto nas ruas, praças, salas de aula de Natal, que impressionou Paulo Herôncio, a ponto de se ter gravado em seu coração uma pequena notícia, distribuída pela agência Havas, publicada no dia 6 de agosto de 1936 em jornais das cidades do Rio de Janeiro e São Paulo e republicada dois dias depois por A Ordem em Natal.

Esta notícia foi intitulada pelo jornal da Diocese como "A guerra continua na Espanha" e de suas retrancas (termo do jargão jornalístico que designa um subtópico da notícia, norteado pelo seu primeiro parágrafo, o lead da matéria). Uma destas retrancas, nomeada como "Verdadeira Barbaria", dizia da impressão de Miguel de Unamuno, escritor católico, lamentando a situação de seu país e dizendo que a luta havia assumido, de ambos os lados, a proporções de barbaria, com fuzilamentos, incêndios, etc. E mais: noutra retranca, se apontava que em Navarra todos os homens válidos estavam sen-

\footnotetext{
${ }^{25}$ CABRAL, José. Duas Palavras. In: HERÔNCIO, Paulo. Os Holandeses no Rio Grande. $1^{\mathrm{a}}$ ed. Rio de Janeiro: Empresa Editora ABC Limitada, 1937, p. 5.

${ }^{26}$ HERÔNCIO, Paulo. Os Holandeses no Rio Grande. $1^{\text {a }}$ ed. Rio de Janeiro: Empresa Editora ABC Limitada, 1937, p. 5.
} 
do recrutados, fossem carlistas, falangistas ou fascistas, não importava a origem política, para lutar contra os republicanos.

Contudo, no tocante aos carlistas, descrevia que estes traziam a boina vermelha e amarela - as cores da Espanha -, e que esses tradicionalistas tinham como palavra de ordem "Por Deus, pela Pátria e pelo Rei" e [...] ostentavam medalhas da Virgem ou de santos regionais que indicam o caráter religioso, "que ainda não foi suficientemente salientado" da guerra civil espanhola. ${ }^{27}$

A impressão de Unamuno se encaixava admiravelmente, mesmo com a diferença de tom, à que o próprio Herôncio havia explicitado apenas alguns dias antes, em dois de agosto, num artigo para o jornal da Diocese, sob o título "Barbaria e Civilização":

Paulo Herôncio entendia já não ser mais possível equiparar os comunistas aos bárbaros de outrora. Se o sentido da oposição dos bárbaros à civilização romana podia ser compreendido e se a ideia de Humanidade era entrevista na convivência dos Bárbaros com a natureza e no culto que eles prestavam aos seus deuses, tais coisas já não eram observáveis na atuação dos Comunistas. Segundo Herôncio, agora estava, de um lado, o patrimônio sagrado da civilização cristã; do outro a volta do homem ao estado selvagem - o rebaixamento da personalidade humana - com o predomínio da matéria e o absolutismo das paixões; com a negação de Deus e a negação da vida futura. A "horda moderna", embora compartilhasse o mesmo legado que o cristianismo e habitasse o mesmo espaço, fazia da destruição material e simbólica do patrimônio da civilização cristã sua principal propaganda e mobilização. ${ }^{28}$

No caso de Os Holandeses no Rio Grande, Paulo Herôncio deixou claro que a identidade católica norte-rio-grandense se forjava na resistência e na negação absoluta à barbaria; ele explicitou o caráter religioso da guerra civil espanhola por meio de um rastro que a encadeia à notícia "A guerra continua na Espanha" e aos carlistas, nas linhas finais de seu livro - Os holandeses haviam fugido, deixando a terra que tanto martirizaram e que se tornou sagrada pelo sangue generoso dos sacrificados por Deus, pela Pátria e pelo Rei. ${ }^{29}$

A "horda moderna" fora enxergada por Paulo Herôncio na experimentação do seu tempo, para depois ser metaforizada em Os Holandeses no Rio Grande, por meio da narrativa de destruição da terra e do genocídio de seus habitantes pelos holandeses, exemplificada pelos eventos de Cunhaú e Uruaçu em 1645.

\footnotetext{
${ }^{27}$ A GUERRA CONTINUA NA ESPANHA. A Ordem, Natal, 8 ago. 1936, p. 4.

${ }^{28}$ PEIXOTO, Duas Palavras..., p. 46.

${ }^{29}$ Ibidem.
} 
Por conseguinte, Os Holandeses no Rio Grande nos lembra não apenas da necessidade de revermos a aproximação da História Política com a História da Religião, mas de repensarmos o estatuto da relação do espaço com a história e a historiografia, de modo a que possamos reconhecer a polissemia de sentidos com que o padre José Cabral enalteceu Paulo Herôncio em seu livro: "Bem haja a quem serve a Deus e trabalha em prol da terra natal". ${ }^{30}$

Artigo recebido para publicação em 26/10/2015

Artigo aprovado para publicação em 04/11/2015

${ }^{30}$ CABRAL, op. cit., p. 7. 